\title{
MODEL EDUCATION RECONSTRUCTION MODUL PERKULIAHAN PENELITIAN LABORATORIUM BERBASIS PROBLEM SOLVING-DECISION MAKING
}

\author{
Florida Doloksaribu ${ }^{1}$, Ahmad Mudzakir ${ }^{2}$, Hayat Sholihin ${ }^{2}$,Fransisca Sudargo ${ }^{2}$ \\ ${ }^{1}$ Universitas Cenderawasih Jayapura; \\ ${ }^{2}$ Universitas Pendidikan Indonesia Bandung, \\ florida_uncen@yahoo.com
}

\begin{abstract}
This research aims to develop teaching instruction material on the subject of Research Laboratory (PL) at Universitas Cendrawasih, Papua. Based on the concept of reseach and development (R\&D), the material, on the topic of limestone, is developed based on model of educational reconstruction (MER). Using Problem Solving Decision Making (PSDM) approach, the study involved five experts to validate the instructional material. Based on the experts' responses, it showed that the material has met the following criteria, namely, accuracy of the material (content and context), the appropriateness between content and context, the suitability of the material with the curriculum (learning objectives), the accuracy of the image and the experimental task, and the suitability of the material with the ability of the students. The value content validity ratio (CVR) for the teaching material was 0.84 which means CVIh > CVIt $(0.84>0.73)$. This indicates that the developed teaching material was suitable to be used by chemical education students.
\end{abstract}

Keywords: laboratory research subjects (PL), teaching materials , Problem Solving Decision Making (PSDM )

\begin{abstract}
Abstrak
Penelitian ini bertujuan untuk mengembangkan bahan ajar pada matakuliah Penelitian Laboratorium (PL) di Universitas Cendrawasih, Papua. Penelitian menggunakan metode reseach and development (R\&D) yaitu mengembangkan bahan ajar perkuliahan berdasarkan Model of educational reconstruction (MER). Topik yang dipilih untuk dikembangkan adalah konteks kimia batu gamping yang dilakukan dengan pendekatan Problem Solving-Decision Making (PSDM). Penelitian melibatkan lima orang ahli untuk memvalidasi bahan ajar yang telah dibuat. Berdasarkan respon ahli didapatkan hasil bahan ajar perkuliahan topik konteks kimia batu gamping berbasis PSDM telah memenuhi kriteria sebagai berikut ketepatan materi (konten dan konteks), kesesuaian antara konten dan konteks, kesesuaian materi dengan kurikulum (tujuan pembelajaran), ketepatan gambar dan tugas percobaan, dan kesesuaian materi dengan kemampuan mahasiswa. Nilai content validity ratio (CVR) rata-rata untuk bahan ajar perkuliahan adalah $0,84, \mathrm{CV}_{\mathrm{Ih}}>\mathrm{CV}_{\mathrm{It}}(0,84>0,73)$, hal ini menandakan bahwa bahan ajar perkuliahan yang dikembangkan layak digunakan untuk mahasiswa pendidikan kimia.
\end{abstract}

Kata Kunci: mata kuliah penelitian laboratorium (PL), bahan ajar, Problem Solving Decision Making (PSDM)

\section{PENDAHULUAN}

Matakuliah Penelitian Laboratorium disajikan sebagai matakuliah wajib bagi mahasiswa calon guru kimia UNCEN, tujuannya untuk mengemban misi perkuliahan dan standar kelulusan yang mampu mengelola secara sains sumber daya alam Papua yang berlimpah. Mahasiswa calon guru kimia selain professional dibidang pengajaran juga harus professional di bidang penelitian laboratorium. Untuk dapat mencapai tujuan perkuliahan mahasiswa perlu dibekali pemahaman konsep penelitian laboratorium secara bermakna yang ditunjang dengan strategi perencanaan penelitian melalui konteks yang diteliti. Mengarahkan pola berpikir penelitian pada perencanaan penelitian seperti seleksi topik, mengidentifikasi masalah, mencari teori pendukung yang relevan, memulai bertanya tentang penelitian atau hipotesis, mengidentifikasi desain penelitian, metode, dan pendekatan identifikasi analisis data. Dengan demikian perkuliahan PL yang disinerjikan dengan mata kuliah pilihan dapat terlaksana secara efektif.

Menurut Skoumios dan Passalis (2010), banyak penelitian yang ditemukan di lapangan tidak mencerminkan penggalian ide sesungguhnya, tetapi cenderung sebagai pelaksanaan tugas yang harus dipenuhi dalam menyelesaikan tugas akhir, sehingga kelihatan lebih cenderung sebagai penelitian plagiarism.

Dalam memahami konsep penelitian laboratorium ada hal yang harus dipikirkan 
sehingga dapat menindak lanjuti penelitian, mengarahkan berpikir pada perencanaan penelitian yang berpedoman pada 1) seleksi topik, 2) mengidentifikasi masalah penelitian, 3) mencari teori-teori pendukung/literatur 4) memulai bertanya tentang penelitian atau hipotesis, 5) mengidentifikasi desain penelitian, 6) metode determinasi, 7) pendekatan mengidentifikasi analisis data (Ross \& Morrison, 2003). Untuk tujuan di atas sebaiknya para tenaga pendidik membuat suatu rancangan perkuliahan yang dapat memacu berpikir mahasiswa dalam melakukan penelitian, untuk meningkatkan kognitif, afektif,dan psikomotorik dalam keterampilan laboratorium. (Donnel et al. 2007). Keterampilan berpikir pada penelitian sangat diperlukan oleh mahasiswa agar dapat melaksanakan suatu perencanaan penelitian yang lebih bermakna. Selain itu mahasiswa harus memahami pola, tata cara, dan tahapan yang harus dilaksanakan. Menurut Ross \& Morisson (2003), dalam penelitian ada beberapa langkah yang harus di ikuti dan perlu di pahami oleh mahasiswa seperti: 1) pentingnya memilih topik untuk memberikan daya tarik pembaca atau yang ingin mendalami penelitian, 2) mengidentifikasi masalah penelitian, dalam hal ini agar si peneliti dapat memberi batasan penelitian, 3) literatur, yaitu untuk mencari informasi penting dan relevan dengan penelitian yang akan dilakukan dalam hal literatur dasar, 4) pertanyaan penelitian atau hipotesis 5) metode penelitian, 6) teknik analisis data, 7) hasil, diskusi, dan publikasi penelitian.

Tahapan pengambilan keputusan dimana solusi benar-benar dilaksanakan yaitu: 1) bingkai masalah: apa yang diputuskan dan mengapa hal itu diputuskan, 2) memilih orang yang tepat yang dapat membantu langkah-langkah pengambilan keputusan, 3) proses yang benar sesuai dengan signifikansi dan kompleksitas keputusan, 4) sebuah set alternatif lengkap yang tergantung pada bagaimana pertanyaan dibingkai, yaitu secara lengkap dan berbeda satu sama lain, 5) menetapkan nilai preferensi alternatif yang dapat dinyatakan dengan atribut yang diinginkan dan tidak diinginkan, 6) informasi yang menggambarkan nilai dari alternatif. Pengambilan keputusan yang baik tidak hanya menuntut fakta-fakta tetapi memahami batas-batas pengetahuan.

Modul perkuliahan yang didesain berdasarkan Model of educational reconstruction (MER) (Duit, et al. 2012 ) dengan tujuan spesifik menyediakan kerangka teori untuk peserta didik agar bermanfaat dan memungkinkan untuk mengajarkan fakta sains dengan komponen analisis struktur konten, penelitian mengajar dan belajar,dan pengembangan dan evaluasi pelajaran untuk mengklarifikasi konsepsi sains spesifik dan struktur konten dari sudut pandang pendidikan. Penyajian konten secara ilmiah langsung dari buku teks merupakan hal yang tidak accessible karena itu perlu "penyederhanaan".

\section{METODE PENELITIAN}

Metode penelitian adalah rekonstruksi didaktis perkuliahan penelitian PL pada konteks kimia batu gamping berbasis PSDM. Tujuannya untuk memenuhi kebutuhan perkuliahan dalam meningkatkan berpikir penelitian mahasiswa. Metode penelitian dan pengembangan (educational research dan development) MER (Duit et al., 2012).

\section{HASIL DAN PEMBAHASAN}

Hasil penelitian yang diperoleh meliputi karakteristik bahan ajar penelitian laboratorium konteks lempung berbasis PSDM, gambaran persfektif mahasiswa terhadap isu penelitian laboratorium konteks lempung berbasis PSDM, .penilaian para ahli terhadap bahan ajar perkuliahan penelitian laboratorium konteks lempung berbasis PSDM. Bahan ajar yang dikembangkan sesuai dengan aspek kompetensi dan sikap problem solving decision making MBTI- 2007 dan beberapa sikap PSDM yang dikembangkan melalui kriteria PSDM berdasarkan tinjauan pustaka yang dibangun kembali dengan memperhatikan tujuan pendidikan pada aspek kognitif dan afektif dan psikomotorik (Duit et al., 2012) yang didukung dengan kurikulum 2013 dimana peserta didik yang mampu berkompetensi yang ditandai oleh kompetensi sikap, pengetahuan, keterampilan berpikir, dan keterampilan psikomotorik (Tabel 1).

PSDM-MBTI tidak semata-mata berupa pengukuran tingkat pemahaman terhadap penelitian laboratorium, tetapi juga pemahaman terhadap aspek proses (kompetensi) berpikir penelitian, sikap berpikir penelitian, serta kemampuan mengaplikasikan berpikir tersebut pada pengetahuan.

Hasil validasi kesesuaian indikator dengan tujuan perkuliahan terhadap sikap berpikir PSDM, diperoleh indikator yang telah dinyatakan valid. Berikut hasil validasi terhadap kesesuaian indikator dengan tujuan perkulaihan yang ditunjukkan Tabel 2. 
Tabel 1. Kompetensi Sikap, Kompetensi Pengetahuan, Kompetensi Berpikir

\begin{tabular}{|c|c|c|c|}
\hline \multicolumn{2}{|c|}{ Kompetensi berpı1kır (PSDM) sebagai skala sıkap } & \multicolumn{2}{|c|}{ Kompetensi Pengetanuan } \\
\hline \multirow{2}{*}{\multicolumn{2}{|c|}{$\begin{array}{l}\text { Mahasiswa harus menjadi insan yang mandiri, dan } \\
\text { menjauhkan sikap yang tidak memenuhi etika keilmuan } \\
\text { seperti kriteria plagiarism karya orang lain yang akan } \\
\text { memunculkan penelitian yang bersifat plagiarism. }\end{array}$}} & Standar Kompetensi & Kompetensi Dasar \\
\hline & & $\begin{array}{l}\text { Menerapkan konsep } \\
\text { lempung sebagai konteks } \\
\text { penelitian laboratorium } \\
\text { yang berbasis } P S D M\end{array}$ & $\begin{array}{l}\text { 1.1.Memberikan gambaran efektif dari } \\
\text { permasalahan yang dapat digali dari } \\
\text { konsep lempung berdasarkan uraian } \\
\text { dasar, pembentukan, sifat, aplikasi } \\
\text { lempung }\end{array}$ \\
\hline \multicolumn{4}{|l|}{ Sikap MBTI } \\
\hline $\begin{array}{l}\text { Ekstravert: } \\
\text { Menunjukkan kemampuan } \\
\text { mengemukakan masalah } \\
\text { terkait lempung }\end{array}$ & $\begin{array}{l}\text { Berpikir keras dalam } \\
\text { menggali permasalahan } \\
\text { yang terkait lempung. }\end{array}$ & . & $\begin{array}{l}\text { 1.2. Mempertimbangkan konstruksi } \\
\text { permasalahan dengan solusi yang } \\
\text { akan dirancang dalam rumusan } \\
\text { permasalahan }\end{array}$ \\
\hline $\begin{array}{l}\text { Intravert: } \\
\text { Menunjukkan kemampuan } \\
\text { berpikir logik merepleksikan } \\
\text { rmasalah terkait lempung. }\end{array}$ & $\begin{array}{l}\text { Berpikir keras } \\
\text { menyelidiki secara } \\
\text { seksama, dan } \\
\text { merenungkan } \\
\text { permasalahan terkait } \\
\text { lempung. }\end{array}$ & & $\begin{array}{l}\text { 1.3. Mempertimbangkan aplikasi pada } \\
\text { penelitian laboratorium melalui } \\
\text { tahapan berpikir problem solving- } \\
\text { Decision making. }\end{array}$ \\
\hline $\begin{array}{l}\text { Sensing: } \\
\text { Menunjukkan kemampuan } \\
\text { menjabarkan pengalaman } \\
\text { dalam mempraktekkan suatu } \\
\text { solusi. }\end{array}$ & $\begin{array}{l}\text { Menseringkan nilai,ide, } \\
\text { fakta ditemukan secara } \\
\text { induksi mengenai materi } \\
\text { terkait lempung. }\end{array}$ & & $\begin{array}{l}\text { 1.4.Menerapkan poin 1.1.-1.3. dalam } \\
\text { penelitian laboratorium melalui } \\
\text { tahapan berpikir /berbasis PSDM }\end{array}$ \\
\hline $\begin{array}{l}\text { Intuitif: } \\
\text { kemampuan memaknai secara } \\
\text { mendalam tentang fakta, dan } \\
\text { solusi pada situasi } \\
\text { permasalahan yang } \\
\text { menandakan sesuatu prospek } \\
\text { yang bersifat original. }\end{array}$ & $\begin{array}{l}\text { Mengklasifikasi, } \\
\text { mengidentifikasi } \\
\text { permasalahan, } \\
\text { memberikan alas an } \\
\text { secara deduktif dengan } \\
\text { asumsi yang menantang, } \\
\text { secara visualisasi }\end{array}$ & & \\
\hline $\begin{array}{l}\text { Thinking: } \\
\text { Kemampuan memahami suatu } \\
\text { solusi berdasarkan fakta, } \\
\text { model, dan/atau prinsip- } \\
\text { prinsip. }\end{array}$ & $\begin{array}{l}\text { Bagaimana } \\
\text { mengklasifikasi, } \\
\text { menkategorikan, } \\
\text { menganalisis, merangkai } \\
\text { analisis, dan tugas } \\
\text { analisis. }\end{array}$ & & \\
\hline $\begin{array}{l}\text { Feeling: } \\
\text { Kemampuan } \\
\text { mempertimbangkan solusi } \\
\text { yang tepat memberikan } \\
\text { pengaruh kuat pada manusia. }\end{array}$ & $\begin{array}{l}\text { Menseringkan nilai } \\
\text { pribadi, serta mendengar } \\
\text { nilai orang lain. Dan } \\
\text { mengklarifikasi nilai-nilai } \\
\text { tersebut. }\end{array}$ & & \\
\hline $\begin{array}{l}\text { Kemampuan membuat } \\
\text { keputusan yang dapat } \\
\text { diimplemantasikan secara } \\
\text { bertahap sesuai prosedur. }\end{array}$ & $\begin{array}{l}\text { Mengevaluasi, teknik- } \\
\text { teknik evaluasi, rencana } \\
\text { terbalik, dan memilih satu } \\
\text { solusi. }\end{array}$ & & \\
\hline $\begin{array}{l}\text { Solusi-yang fleksibel, dapat } \\
\text { diadaptasi, informasi yang } \\
\text { cukup yang tersedia untuk } \\
\text { solusi yang benar-benar } \\
\text { dipertimbangkan }\end{array}$ & $\begin{array}{l}\text { Memiliki gagasan } \\
\text { cemerlang, dengan } \\
\text { berbagai teknik, dengan } \\
\text { bias diperdebatkan, untuk } \\
\text { membuat perspektif orang } \\
\text { lain. }\end{array}$ & & \\
\hline
\end{tabular}


Tabel 2. Rekapitulasi CVR Indikator dan Tujuan Perkuliahan pada Aspek Kognitif

\begin{tabular}{|c|c|c|c|c|c|}
\hline Konteks & Konten & Proses Kompetensi Standarisasi & Indikator & $\begin{array}{c}\text { Tujuan perkuliahan } \\
\text { aspek kognitif }\end{array}$ & $\begin{array}{c}\text { CVR } \\
\text { rerata }\end{array}$ \\
\hline $\begin{array}{l}\text { 1.Proses } \\
\text { pem- } \\
\text { bentukan } \\
\text { lempung }\end{array}$ & $\begin{array}{l}\text { 1.1.Pem- } \\
\text { bentukan } \\
\text { lempung } \\
\text { secara } \\
\text { residual dan } \\
\text { sedimentasi }\end{array}$ & $\begin{array}{l}\text { Mengidentifikasi, merumuskan, } \\
\text { mengeksplorasi strategi } \\
\text { pemecahan, melaksanakan } \\
\text { strategi pemecahan, mengevaluasi } \\
\text { strategi masalah berkaitan dengan } \\
\text { proses pembentukan lempung. }\end{array}$ & $\begin{array}{l}\text { Menjelaskan proses } \\
\text { pembentukan } \\
\text { lempung }\end{array}$ & $\begin{array}{l}\text { 1.1. 1.Mahasiswa } \\
\text { mampu mengungkap } \\
\text { berbagai masalah } \\
\text { melalui proses } \\
\text { pembentukan lempung. } \\
\text { 1.1.2.Mahasiswa mampu } \\
\text { memberikan gambaran } \\
\text { efektif dari } \\
\text { permasalahan yang } \\
\text { terungkap seputar } \\
\text { pembentukan lempung. }\end{array}$ & 0,66 \\
\hline $\begin{array}{l}\text { 2.Sifat- } \\
\text { sifat } \\
\text { fisika- } \\
\text { kimia }\end{array}$ & $\begin{array}{l}\text { 2.1.Sifat } \\
\text { fisika dan } \\
\text { sifat kimia } \\
\text { lempung }\end{array}$ & $\begin{array}{l}\text { Mengidentifikasi masalah, } \\
\text { merumuskan masalah, } \\
\text { mengeksplorasi strategi } \\
\text { pemecahan, melaksanakan } \\
\text { strategi, dan mengevaluasi } \\
\text { strategi masalah berkaitan dengan } \\
\text { sifat fiika kimia. }\end{array}$ & $\begin{array}{l}\text { Menjelaskan dan } \\
\text { memahami sifat-sifat } \\
\text { fisika kimia pada } \\
\text { lempung }\end{array}$ & $\begin{array}{l}\text { 2.1. 1.Mahasiswa } \\
\text { mampu menjelaskan } \\
\text { tujuan pengungkapan } \\
\text { masalah, merumuskan, } \\
\text { solusi evaluasi masalah } \\
\text { berkaitan dengan sifat } \\
\text { fisika kimia lempung }\end{array}$ & 0,88 \\
\hline \multirow[t]{6}{*}{$\begin{array}{l}\text { 3.Manfaat } \\
\text { lempung }\end{array}$} & $\begin{array}{l}3.1 . \\
\text { Lempung } \\
\text { sebagai } \\
\text { bahan } \\
\text { isolator }\end{array}$ & $\begin{array}{l}\text { Mengidentifikasi, merumuskan } \\
\text { masalah, mengeksplorasi strategi } \\
\text { pemecahan masalah, } \\
\text { melaksanakan strategi pemecahan } \\
\text { masalah, mengevaluasi strategi } \\
\text { masalah berdasarkan manfaat } \\
\text { lempung dibidang kelistrikan. }\end{array}$ & $\begin{array}{l}\text { Menyelidiki, } \\
\text { mengungkap, } \\
\text { menjelaskan, dan } \\
\text { memahami peran } \\
\text { lempung sebagai } \\
\text { bahan isolator }\end{array}$ & $\begin{array}{l}\text { 3.1.1.Mahasiswa mampu } \\
\text { menjelaskan masalah } \\
\text { yang terdapat disekitar } \\
\text { kehidupan, dengan } \\
\text { mengemukakan peranan } \\
\text { lempung sebagai salah } \\
\text { satu pemecah masalah } \\
\text { dibidang kelistrikan. }\end{array}$ & 0,88 \\
\hline & $\begin{array}{l}3.2 \text {. } \\
\text { Lempung } \\
\text { sebagai } \\
\text { bahan } \\
\text { adsorbsi }\end{array}$ & $\begin{array}{l}\text { Mengidentifikasi masalah, } \\
\text { merumuskan masalah, } \\
\text { mengeksplorasi strategi } \\
\text { pemecahan masalah, } \\
\text { melaksanakan strategi pemecahan } \\
\text { masalah, mengevaluasi strategi } \\
\text { masalah berdasarkan manfaat } \\
\text { lempung dibidang adsorbsi. }\end{array}$ & $\begin{array}{l}\text { Menyelidiki, } \\
\text { mengungkap, } \\
\text { menjelaskan, } \\
\text { memahami manfaat } \\
\text { lempung sebagai } \\
\text { adsorbsi. }\end{array}$ & $\begin{array}{l}\text { 3.2.1. Mahasiswa mampu } \\
\text { memberikan suatu } \\
\text { gambaran permasalahan } \\
\text { yang berhubungan } \\
\text { dengan peranan } \\
\text { lempung sebagai bahan } \\
\text { adsorbsi. }\end{array}$ & 1 \\
\hline & $\begin{array}{l}3.3 \text {. } \\
\text { Lempung } \\
\text { sebagai } \\
\text { bahan } \\
\text { komposit }\end{array}$ & $\begin{array}{l}\text { Mengidentifikasi masalah, } \\
\text { merumuskan masalah, } \\
\text { mengeksplorasi strategi } \\
\text { pemecahan masalah, } \\
\text { melaksanakan strategi pemecahan } \\
\text { masalah, mengevaluasi strategi } \\
\text { masalah berdasarkan manfaat } \\
\text { lempung sebagai bahan } \\
\text { filler/pengisi. }\end{array}$ & $\begin{array}{l}\text { Menyelidiki, } \\
\text { mengungkap, } \\
\text { menjelaskan, dan } \\
\text { memahami manfaat } \\
\text { lempung sebagai } \\
\text { bahan pengisi/filler. }\end{array}$ & $\begin{array}{l}\text { 3.3.1. Mahasiswa mampu } \\
\text { menjelaskan, memahami } \\
\text { kontribusi lempung } \\
\text { sebagai bahan pengisi. }\end{array}$ & 0,88 \\
\hline & $\begin{array}{l}3.4 \text {. } \\
\text { Lempung } \\
\text { sebagai } \\
\text { pencegah } \\
\text { pencemaran } \\
\text { lahan }\end{array}$ & $\begin{array}{l}\text { Mengidentifikasi masalah, } \\
\text { merumuskan masalah, } \\
\text { mengeksplorasi strategi } \\
\text { pemecahan masalah, } \\
\text { melaksanakan strategi pemecahan } \\
\text { masalah, mengevaluasi strategi } \\
\text { masalah berdasarkan pencemaran } \\
\text { lahan pertanian. }\end{array}$ & $\begin{array}{l}\text { Menyelidiki, } \\
\text { mengungkap, } \\
\text { menjelaskan, dan } \\
\text { memahami manfaat } \\
\text { lempung sebagai } \\
\text { bahan pencegah } \\
\text { pencemaran lahan } \\
\text { pertanian. }\end{array}$ & $\begin{array}{l}\text { 3.3.2. Mahasiswa } \\
\text { mampu menjelaskan, } \\
\text { memahami kontribusi } \\
\text { lempung sebagai bahan } \\
\text { pencegahan pencemaran } \\
\text { lahan pertanian. }\end{array}$ & 0,88 \\
\hline & $\begin{array}{l}3.5 . \\
\text { Lempung } \\
\text { sebagai } \\
\text { pemilar }\end{array}$ & $\begin{array}{l}\text { Mengidentifikasi masalah, } \\
\text { merumuskan masalah, } \\
\text { mengeksplorasi strategi } \\
\text { pemecahan masalah, } \\
\text { melaksanakan strategi pemecahan } \\
\text { masalah, mengevaluasi strategi } \\
\text { masalah berdasarkan kemampuan } \\
\text { lempung sebagai bahan pemilar. }\end{array}$ & $\begin{array}{l}\text { Menyelidiki, } \\
\text { mengungkap, } \\
\text { menjelaskan, dan } \\
\text { memahami manfaat } \\
\text { lempung sebagai } \\
\text { bahan pencegah } \\
\text { pencemaran lahan } \\
\text { pertanian. }\end{array}$ & $\begin{array}{l}\text { 3.3.2. Mahasiswa } \\
\text { mampu menjelaskan, } \\
\text { memahami kontribusi } \\
\text { lempung sebagai bahan } \\
\text { pemilar. }\end{array}$ & 0,77 \\
\hline & & & & CVR & $\mathbf{0 , 8 4}$ \\
\hline
\end{tabular}


Nilai CVR diperoleh melalaui rumus $C V R=$ $\frac{N e-\left(\frac{N}{2}\right)}{N / 2}$, dengan validator 5 orang hasil validasi

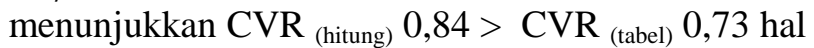
ini menunjukkan indikator dan tujuan perkuliahan dengan aspek kognitif adalah valid.

Pada penelitian ini ada empat buku teks yang dijadikan acuan dalam melakukan analisis konten secara kualitatif yaitu principles of mineralogi, bahan galian industri, descriptive inorganic chemistry, dan mineralogy of carbonatites. Secara keseluruhan tampilan naskah dari beberapa buku teks meliputi: pengantar, isi pokok, penilaian, dan rangkuman. Konten sains harus diproses sesuai dengan rekonstruksi didaktis (Duit et al., 2012). Sehingga struktur konten asli dari buku teks asli yang sudah ditetapkan, dipindahkan kedalam struktur konten perkuliahan melalui tahap elementasi dan konstruksi "proses penyederhanaan" untuk pengurangan tingkat kesulitan bahan ajar agar mahasiswa dapat memahami dengan mudah melalui penghalusan, penyisipan dan penghapusan kata atau frasa seperti yang ditunjukkan Tabel 3 dan Tabel 4.

Berdasarkan Tabel 4, CVR hitung $0.82>$ dari CVR tabel 0,73 hal ini menunjukkan indikator dan tujuan perkuliahan pada aspek sikap PSDM MBTI dapat diterima.

Tabel 3. Klarifikasi dan Analisis Kimia Bahan Galian Konteks Lempung (Klarifikasi Materi Subjek Teks Asli Lempung)

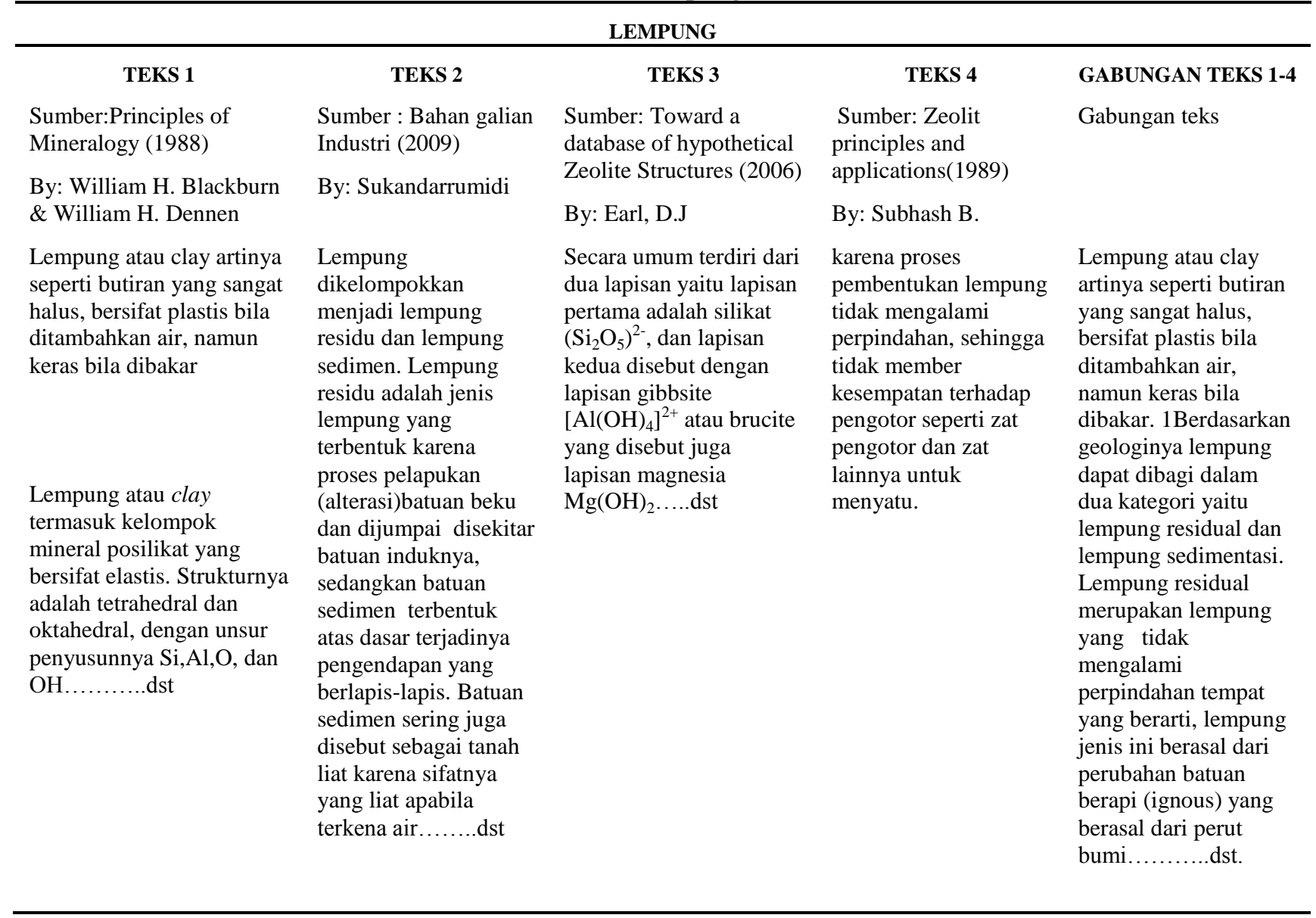


Tabel 4. Teks Konten Lempung Berbasis Problem Solving-Decision Making

Teks Dasar Teks berbasis PSDM

Lempung atau clay merupakan butiran yang sangat halus, bersifat plastis/elastis bila ditambahkan air, namun keras bila dibakar. Berdasarkan geologinya lempung dapat dibagi dalam dua kategori yaitu lempung residual dan lempung sedimentasi.

Lempung residual merupakan lempung yang tidak mengalami perpindahan tempat yang berarti, lempung jenis ini berasal dari perubahan batuan berapi (ignous) yang berasal dari perut bumi, ketika terjadi tenaga endogen seperti ledakan gunung berapi dan terjadi pergeseran di areal tersebut tanpa sempat terbawa ke area lain. Perubahan karena kekuatan endogen terjadi di bawah permukaan bumi yang disebabkan oleh panas dan bahan-bahan kimia. Contoh adalah proses kaolinisasi, yaitu proses pembentukan kaolin karena pelapukan dan proses hidrotermal pada batuan beku yang banyak mengandung feldsfar, dimana mineral potassium aluminium silikat dan feldsfar dirubah menjadi kaolin. Proses pelapukan (alterasi) batuan beku dijumpai disekitar batuan induknya, kemurnian yang tinggi dari lempung ini dapat dimengerti karena proses pembentukan lempung tidak mengalami perpindahan, sehingga tidak memberi kesempatan terhadap zat pengotor dan zat lainnya untuk menyatu.

Sedangkan batuan sedimen terbentuk berdasarkan pengendapan yang berlapis-lapis. Batuan sedimen sering juga disebut sebagai tanah liat karena sifatnya yang liat apabila terkena air. Lempung jenis ini merupakan hasil desintegrasi, pelapukan kimia, terutama pengaruh $\mathrm{H}_{2} \mathrm{O}$ dan $\mathrm{CO}_{2}$ yang dibantu oleh mikroorganisma terhadap batuan induk. Hasilnya merupakan bagian yang halus dan tidak larut dalam air. Selanjutnya material ini diangkut oleh air sebagai suspensi dan akhirnya mengendap secara berlapis-lapis. Selama proses pengendapan/pengangkutan sangat dimungkinkan dikotori oleh mineral yang berukuran halus antara lain kuarsa, besi oksida, dan bahan organis.

Reaksi pembentukan lempung ini adalah sebagai berikut : $2 \mathrm{KAlSi}_{3} \mathrm{O}_{8}+2 \mathrm{H}_{2} \mathrm{O}+\mathrm{CO}_{2} \rightarrow \mathrm{Al}_{2} \mathrm{O}_{3} \mathrm{SiO}_{2} \cdot 2 \mathrm{H}_{2} \mathrm{O}+4 \mathrm{SiO}_{2}+$ $\mathrm{K}_{2} \mathrm{CO}_{3}$

Lempung memiliki butiran yang sangat halus lebih kecil dari 2 mikron.Untuk membuang air pada semua pori lempung dibuthkan suhu $450-750^{\circ} \mathrm{C}$, sedangkan untuk membuang gas $\mathrm{CO}_{2}, \mathrm{SO}_{3}$, dan gips dari batuan karbonat suhu ditingkatkan antara $950-1250^{\circ} \mathrm{C}$, selama waktu pemanasan $\mathrm{FeO}$ dapat berubah menjadi $\mathrm{Fe}_{2} \mathrm{O}_{3}$, sehingga warnanyapun akan lebih merah dan kekuatan mekanis dari bahan akan semakin meningkat. Dalam keadaan itu pula beberapa mineral ikutan seperti feldsfar akan meleleh dan akan mengalir disekitar pori, bila sudah dingin maka mineral tersebut akan mengeras.Warna dari hasil produksi pembakaran tergantung dari suhu pembakaran, dan juga perbandingan banyaknya kandungan $\mathrm{Fe}_{2} \mathrm{O}_{2}, \mathrm{CaO}^{+}$dan $\mathrm{Al}_{2} \mathrm{O}_{3}$. Makin banyak $\mathrm{Fe}_{2} \mathrm{O}_{3}$ makin merah warna lempung dan sebaliknya. Apabila lempung yang mengandung bahan organisma dibakar, maka strukturnya semakin berpori karena gas $\mathrm{CO}_{2}$ dari hasil pembakaran akan keluar. Bahan organis ini berasal dari tumbuhan atau binatang..............dst.
Lempung atau clay merupakan butiran yang sangat halus, bersifat plastis/elastis bila ditambahkan air, namun keras bila dibakar. Lempung termasuk kelompok mineral posilikat dengan struktur tetrahedral dan oktahedral dan unsur penyusunnya adalah $\mathrm{Si}, \mathrm{Al}, \mathrm{O}$, dan $\mathrm{OH}$. Pada dasarnya unsur pembangun mineral lempung merupakan susunan dimensi dua tetrahedral silikon-oksigen dan susunan dimensi dua oktahedral aluminium-oksigenhidroksil. Sebagian besar lembaran mineral lempung tersusun secara berlapislapis ke atas dalam susunan yang berbeda-beda.

Berdasarkan geologinya lempung dapat dibagi dalam dua kategori yaitu lempung residual dan lempung sedimentasi. Lempung residual merupakan lempung yang tidak mengalami perpindahan tempat yang berarti, lempung jenis ini berasal dari perubahan batuan berapi (ignous) yang berasal dari perut bumi, ketika terjadi tenaga endogen seperti ledakan gunung berapi dan terjadi pergeseran di areal tersebut tanpa sempat terbawa ke area lain. Perubahan karena kekuatan endogen terjadi di bawah permukaan bumi yang disebabkan oleh panas dan bahan-bahan kimia. Contoh adalah proses kaolinisasi, yaitu proses pembentukan kaolin karena pelapukan dan proses hidrotermal pada batuan beku yang banyak mengandung feldsfar, dimana mineral potassium aluminium silikat dan feldsfar dirubah menjadi kaolin. Proses pelapukan (alterasi) batuan beku dijumpai disekitar batuan induknya, kemurnian yang tinggi dari lempung ini dapat dimengerti karena proses pembentukan lempung tidak mengalami perpindahan, sehingga tidak memberi kesempatan terhadap zat pengotor dan zat lainnya untuk menyatu.

Sedangkan batuan sedimen terbentuk berdasarkan pengendapan yang berlapis-lapis. Batuan sedimen sering juga disebut sebagai tanah liat karena sifatnya yang liat apabila terkena air. Lempung jenis ini merupakan hasil desintegrasi, pelapukan kimia, terutama pengaruh $\mathrm{H}_{2} \mathrm{O}$ dan $\mathrm{CO}_{2}$ yang dibantu oleh mikroorganisma terhadap batuan induk. Hasilnya merupakan bagian yang halus dan tidak larut dalam air. Selanjutnya material ini diangkut oleh air sebagai suspensi dan akhirnya mengendap secara berlapis-lapis. Selama proses pengendapan/ pengangkutan sangat dimungkinkan dikotori oleh mineral yang berukuran halus antara lain kuarsa, besi oksida, dan bahan organis. Keadaan ini dilihat seperti pada gambar 3.1. Reaksi pembentukan lempung ini adalah,

$2 \mathrm{KAlSi}_{3} \mathrm{O}_{8}+2 \mathrm{H}_{2} \mathrm{O}+\mathrm{CO}_{2} \rightarrow \mathrm{Al}_{2} \mathrm{O}_{3} \mathrm{SiO}_{2} \cdot 2 \mathrm{H}_{2} \mathrm{O}+4 \mathrm{SiO}_{2}+\mathrm{K}_{2} \mathrm{CO}$

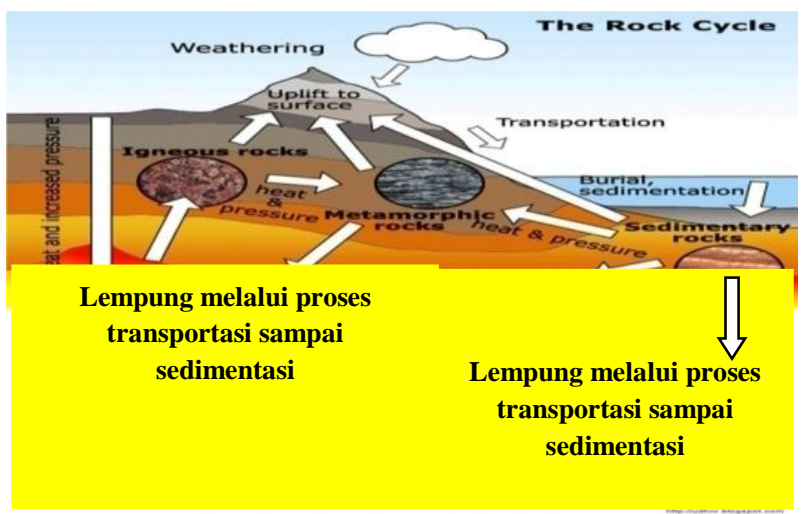

Proses pembentukan lempung secara residu dan sedimentasi

Mari diskusi membedah konsep: Berdasarkan proses pembentukan lempung, dapatkah anda memberikan gambaran atau ide yang dapat diangkat menjadi suatu rancangan penelitian laboratorium ? 
Tabel 4. Rekapitulasi CVR Indikator dan Tujuan Perkuliahan Aspek Sikap PSDM MBTI

\begin{tabular}{|c|c|c|c|c|c|}
\hline Konteks & Konten & Sikap PSDM-MBTI & Indikator & $\begin{array}{c}\text { Tujuan } \\
\text { Perkuliahan } \\
\text { aspek sikap } \\
\end{array}$ & $\overline{c v r}$ \\
\hline $\begin{array}{l}\text { 1.Pembentukan } \\
\text { lempung }\end{array}$ & $\begin{array}{l}\text { Secara } \\
\text { Residual } \\
\text { dan } \\
\text { Sedimentasi }\end{array}$ & $\begin{array}{l}\text { 1. Ekstravert: } \\
\text { Menunjukkan kemampuan } \\
\text { mengemukakan } \\
\text { permasalahan terkait } \\
\text { lempung }\end{array}$ & $\begin{array}{l}\text { Berpikir keras dalam menggali } \\
\text { permasalahan yang berkaitan } \\
\text { dengan lempung. }\end{array}$ & $\begin{array}{l}\text { Mahasiswa } \\
\text { tidak } \\
\text { melakukan aksi } \\
\text { meniru, } \\
\text { menjiplak, } \\
\text { sikap } \\
\text { plagiarism } \\
\text { terkait } \\
\text { lempung. }\end{array}$ & 1 \\
\hline $\begin{array}{l}\text { 2. Sifat-sifat } \\
\text { lempung }\end{array}$ & $\begin{array}{l}\text { Sifat fisika } \\
\text { dan sifat } \\
\text { kimia } \\
\text { lempung }\end{array}$ & $\begin{array}{l}\text { 2. Intravert: } \\
\text { Menunjukkan kemampuan } \\
\text { berpikir } \\
\text { logik dengan ide-ide } \\
\text { cemerlang yang mampu } \\
\text { merepleksikan } \\
\text { permasalahan terkait } \\
\text { lempung. }\end{array}$ & $\begin{array}{l}\text { Berpikir keras dengan } \\
\text { menyelidiki secara seksama, } \\
\text { dan merenungkan } \\
\text { permasalahan yang ditemukan } \\
\text { berkaitan dengan lempung. }\end{array}$ & & 0,77 \\
\hline \multirow{6}{*}{$\begin{array}{l}\text { 3. Manfaat } \\
\text { lempung }\end{array}$} & $\begin{array}{l}\text { Lempung } \\
\text { sebagai } \\
\text { bahan } \\
\text { adsorban }\end{array}$ & $\begin{array}{l}\text { Menunjukkan kemampuan } \\
\text { menjabarkan pengalaman } \\
\text { diri, mempraktekkan suatu } \\
\text { solusi sesuai dengan } \\
\text { kemampuan diri terkait } \\
\text { lempung. } \\
\text { 4. Intuitif: } \\
\text { kemampuan memaknai } \\
\text { mendalam tentang fakta- } \\
\text { fakta, dan solusi-solusi } \\
\text { pada permasalahan yang } \\
\text { menandakan sesuatu } \\
\text { prospek yang bersifat } \\
\text { original terkait lempung. }\end{array}$ & $\begin{array}{l}\text { Menseringkan (share) ide-ide, } \\
\text { dan fakta-fakta yang } \\
\text { ditemukan secara induksi } \\
\text { mengenai materi yang } \\
\text { berkaitan dengan lempung. } \\
\text { Mengklasifikasi, } \\
\text { mengidentifikasi, } \\
\text { memberikan alasan secara } \\
\text { deduktif dengan asumsi yang } \\
\text { menantang, memberikan } \\
\text { gambaran secara } \\
\text { visualisasi,dan mensintesis } \\
\text { materi terkait lempung. }\end{array}$ & & 0,88 \\
\hline & $\begin{array}{l}\text { Lempung } \\
\text { sebagai } \\
\text { bahan } \\
\text { pengisi }\end{array}$ & $\begin{array}{l}\text { 5. Thinking: } \\
\text { Kemampuan memahami } \\
\text { suatu solusi-solusi } \\
\text { berdasarkan ffakta, } \\
\text { models, prinsip lempung. }\end{array}$ & $\begin{array}{l}\text { Bagaimana mengklasifikasi, } \\
\text { menkategorikan, menganalisis, } \\
\text { merangkai analisis tugas } \\
\text { analisis terkait lempung. }\end{array}$ & & 0,77 \\
\hline & \multirow{4}{*}{$\begin{array}{l}\text { Lempung } \\
\text { sebagai } \\
\text { bahan } \\
\text { pencemaran } \\
\text { lahan } \\
\text { pertanian } \\
\text { Lempung } \\
\text { terpilar }\end{array}$} & $\begin{array}{l}\text { 6. Feeling: } \\
\text { Kemampuan } \\
\text { mempertimbangkan solusi } \\
\text { tepat yang memberikan } \\
\text { pengaruh kuat pada } \\
\text { manusia }\end{array}$ & $\begin{array}{l}\text { Menseringkan nilai-nilai, } \\
\text { serta mendengar nilai-nilai } \\
\text { orang lain, mengklarifikasi } \\
\text { nilai-nilai tersebut untuk } \\
\text { mengungkap ide -ide terkait } \\
\text { lempung. }\end{array}$ & & 0,77 \\
\hline & & $\begin{array}{l}\text { 7. Judging: } \\
\text { Kemampuan membuat } \\
\text { keputusan yang dapat } \\
\text { diimplemantasikan sesuai } \\
\text { dengan prosedur yang } \\
\text { tepat. } \\
\text { 8. Perceiving: }\end{array}$ & $\begin{array}{l}\text { Mengevaluasi, teknik-teknik } \\
\text { evaluasi, rencana terbalik, dan } \\
\text { memilih satu solusi yang tepat } \\
\text { dalam mengungkap ide yang } \\
\text { berkaitan dengan lempung. }\end{array}$ & & 0,77 \\
\hline & & $\begin{array}{l}\text { Solusi-solusi yang } \\
\text { fleksibel dan dapat } \\
\text { diadaptasi, informasi- } \\
\text { informasi terkait lempung } \\
\text { yang cukup tersedia untuk } \\
\text { solusi yang benar-benar } \\
\text { dipertimbangkan. }\end{array}$ & $\begin{array}{l}\text { Memiliki gagasan-gagasan } \\
\text { cemerlang, dengan berbagai } \\
\text { teknik-teknik, dengan bias } \\
\text { yang diperdebatkan, untuk } \\
\text { membuat perspektif orang lain } \\
\text { pada materi lempung. }\end{array}$ & & 0,77 \\
\hline & & & & CVR & $\mathbf{0 , 8 2}$ \\
\hline
\end{tabular}


Tabel 5. Rekapitulasi Penilaian terhadap Rancangan bahan Perkuliahan Penelitian Laboratorium Konteks Batu Lempung Berbasis PSDM

\begin{tabular}{lcccc}
\hline \multicolumn{1}{c}{ Tahapan STL } & $\begin{array}{c}\text { Kesesuaian materi } \\
\text { dengan kurikulum }\end{array}$ & $\begin{array}{c}\text { Ketepatan gambar } \\
\text { dan tugas }\end{array}$ & $\begin{array}{c}\text { Kesesuaian materi : } \\
\text { kemampuan } \\
\text { mahasiswa }\end{array}$ & $\begin{array}{c}\text { CVR rata- } \\
\text { rata }\end{array}$ \\
\hline \multicolumn{1}{c}{ Tahap Kontak } & CVR & CVR & CVR \\
1. Proses pembentukan lempung & 1 & 1 & 0,66 & 0,88 \\
2. Sifat fiika kimia lempung & 0,66 & 0,66 & 0,66 & 0,66 \\
3. Jenis-jenis lempung & 1 & 1 & 0,66 & 0,88 \\
4. Manfaat lempung & 1 & 0,66 & 1 & 0,88 \\
a. Sebagai bahan isolator & 0,66 & 0,66 & 1 & 0,77 \\
b. Sebagai bahan adsorban & 0,66 & 1 & 0,66 & 0,88 \\
c. Sebagai bahan filler & 1 & 0,66 & 1 & 0,77 \\
d. Sebagai Pencegah pencemaran & 0,66 & 1 & 0,66 & 0,88 \\
lahan pertanian & & & 1 & 0,77 \\
e. Sebagai bahan pemilar & 0,66 & & 0,81 \\
\hline
\end{tabular}

Tabel 6. Rekapitulasi Penilaian terhadap Tahapan elaborasi dan Tujuan Perkuliahan Konteks Batu Lempung

\begin{tabular}{|c|c|c|c|c|c|c|c|}
\hline & $\begin{array}{l}\text { Tahapan Elaborasi } \\
\text { Tujuan Perkuliahan }\end{array}$ & $\begin{array}{c}\text { Ketepatan } \\
\text { materi } \\
\text { konten dan } \\
\text { konteks }\end{array}$ & $\begin{array}{c}\text { Kesesuaian } \\
\text { antara konten } \\
\text { dan konteks }\end{array}$ & $\begin{array}{c}\text { Kesesuaian } \\
\text { materi dengan } \\
\text { kurikulum } \\
\text { (tujuan } \\
\text { perkuliahan) } \\
\end{array}$ & $\begin{array}{l}\text { Ketepatan } \\
\text { gambar, } \\
\text { ilustrasi, }\end{array}$ & $\begin{array}{c}\text { Kesesuaian } \\
\text { materi } \\
\text { dengan } \\
\text { kemampuan } \\
\text { mahasiswa } \\
\end{array}$ & $\begin{array}{l}\text { CVR rata- } \\
\text { rata }\end{array}$ \\
\hline & & CVR & CVR & CVR & CVR & CVR & \\
\hline 1 . & $\begin{array}{l}\text { Mahasiswa dapat } \\
\text { menerapkan konsep } \\
\text { pembentukan lempung } \\
\text { pada penelitian } \\
\text { laboratorium berbasis } \\
\text { PSDM }\end{array}$ & 1 & 1 & 0,66 & 1 & 0,66 & 0,86 \\
\hline 2. & $\begin{array}{l}\text { Mahasiswa dapat } \\
\text { menerapkan konsep sifat } \\
\text { fisik-kimia lempung } \\
\text { pada penelitian } \\
\text { laboratorium berbasis } \\
\text { PSDM }\end{array}$ & 0,66 & 0,66 & 0,66 & 0,66 & 1 & 0,72 \\
\hline \multirow[t]{2}{*}{3.} & $\begin{array}{l}\text { Mahasiswa dapat } \\
\text { menerapkan konsep } \\
\text { manfaat lempung pada } \\
\text { penelitian laboratorium } \\
\text { berbasis PSDM }\end{array}$ & 1 & 1 & 0,66 & 0,66 & 0,66 & 0,79 \\
\hline & Tahap Nexus & CRV & CRV & CRV & CRV & CRV & $\begin{array}{l}\text { CVR rata- } \\
\text { rata }\end{array}$ \\
\hline 1. & $\begin{array}{l}\text { Contoh soal } 1 . \\
\text { Pembentukan lempung }\end{array}$ & 1 & 0,66 & 0,66 & 1 & 1 & 0,86 \\
\hline 2. & $\begin{array}{l}\text { Contoh soal 2. Sifat fisik } \\
\text { lempung }\end{array}$ & 1 & 1 & 0,66 & 0,66 & 0,66 & 0,79 \\
\hline 3. & $\begin{array}{l}\text { Contoh soal 3. Manfaat } \\
\text { lempung }\end{array}$ & 0,66 & 0,66 & 1 & 1 & 0,66 & 0,79 \\
\hline \multirow[t]{2}{*}{4.} & Tugas & 0,66 & 0,66 & 0,66 & 1 & 1 & 0,79 \\
\hline & & & & & & CVR & 0,80 \\
\hline
\end{tabular}


Pada Tabel 5 dan Tabel 6 menunjukkan rancangan bahan perkuliahan penelitian laboratorium konteks lempung berbasis PSDM dengan nilai CVR pada tahap kontak adalah 0,80 artinya responden mempunyai persfektif baik terhadap kesesuaian materi dengan kurikulum 2013, ketepatan gambar, serta kesesuaian materi dengan kemampuan mahasiswa, dimana CVI hitung $0,80>\mathrm{CVI}_{\text {tabel } 0,67}$. Komponen pertama MER adalah klarifikasi struktur konten yaitu klarifikasi materi subjek dan analisis signifikansi pendidikan. Pada penelitian ini ada empat buku teks yang dijadikan acuan dalam melakukan analisis konten secara kualitatif yaitu principles of mineralogi, bahan galian industri, descriptive inorganic chemistry, dan mineralogy of carbonatites. Secara keseluruhan tampilan naskah dari beberapa buku teks meliputi: pengantar, isi pokok, penilaian, dan rangkuman yang berisikan tahapan seperti tahapan kontak, dimana dikembangkan isu-isu serta beberapa permasalahan yang terjadi di lingkungan sekitar yaitu, isu pembentukan lempung, sifat fisika kimia lempung, dan pemanfaatan lempung sebagai bahan isolator, bahan adsorben, bahan pengisi, mengatasi pencemaran lahan pertanian, sebagai pilarisasi kimia.

Dalam hal ini agar mahasiswa menyadari dan membuka cakrawala berpikirnya bahwa material lempung merupakan sesuatu yang penting dipahami dan ditelusuri untuk kebutuhan pengembangan ilmu dan sains. Tahap Kuorisiti, pada tahap ini mahasiswa diberikan pertanyaan PSDM sesuai dengan isu atau fakta yang terjadi pada kehidupan sehari-hari. Tahap Elaborasi, pada tahap ini dilakukan eksplorasi, pembentukan dan pemantapan konsep sampai pada tahap kuriositi dapat terjawab. Tahap pengambilan keputusan, melakukan analisis dan evaluasi terhadap masalah yang ada. Tahapan ini mengajak mahasiswa menggali jawaban terkait dengan konteks permasalahan melalui berbagai proses penelusuran terkait batu gamping. Tahap Nexus, tahap ini merupakan fase dekontekstualisasi dan rekontekstualisasi. Penyajian susunan wacana teks yang telah dijabarkan pada bahan perkuliahan yang dirangkum untuk proses pengambilan intisari. Dalam hal ini konteks lain yang dikembangkan adalah mengenai pembentukan lempung, sifat fisika kimia lempung, dan berbagai aplikasi lempung pada bidang kehidupan.

Perspektif mahasiswa terhadap isu PL terkait lempung berbeda-beda. Berdasarkan wawancara dengan 10 pertanyaan pada 10 mahasiswa angkatan yang berbeda-beda yaitu bagaimana keterkaitan konsep lempung pada konteks penelitian laboratorium. Pertanyaan nomor 1-5 menanyakan prakonsepsi mahasiswa tentang lempung sedangkan pertanyaan 6-10 menanyakan tentang sikap dan ketertarikan mahasiswa terhadap isu kimia bahan galian lempung yang telah berkembang.

Tabel 7. Pedoman Wawancara Mahasiswa

\begin{tabular}{ll} 
No. & \multicolumn{1}{c}{ Pertanyaan } \\
\hline 1. & $\begin{array}{l}\text { Apakah anda pernah membaca atau mengetahui } \\
\text { tentang kimia lempung sebagai bahan (isolator, } \\
\text { adsorben,bahan filler,pencegahan pencemaran lahan } \\
\text { pertanian, pilarisasi) ? }\end{array}$ \\
2. $\quad$ Dari manakah anda mendapatkan informasi tersebut? \\
3. $\quad \begin{array}{l}\text { Menurut pendapat anda apakah lempung sangat } \\
\text { berarti bagi perkembangan penelitian kimia? }\end{array}$ \\
B. $\quad \begin{array}{l}\text { Berikanlah salah satu contoh aplikasi lempung pada } \\
\text { kehidupan yang pernah anda ketahui. }\end{array}$ \\
5. $\quad \begin{array}{l}\text { Apakah anda pernah mendengar/atau membaca } \\
\text { tentang permasalahan kimiawi menyangkut lempung? } \\
\text { Dan adakah perbedaan pemahaman anda pada } \\
\text { lempung yang anda lihat selama ini dengan lempung } \\
\text { pada prospek kimiawi? }\end{array}$
\end{tabular}

6. Apakah yang anda pikirkan tentang gambar dibawah ini?

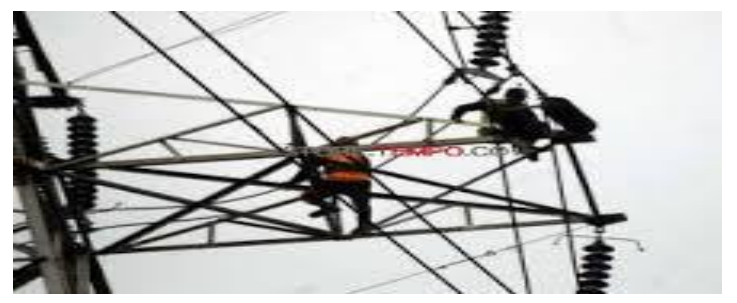

7. Bila ada permasalahan yang anda temui di lingkungan sekitar anda. Solusi apa yang anda dapat berikan, bila hal itu dapat diselesaikan dengan cara mengaplikasikan keberadaan lempung?

8. Pernahkah anda mendengar prinsip-prinsip tentang pengelolaan lingkungan dengan pemanfaatan lempung?, keuntungan apakah yang anda dapat peroleh jika mengikuti prinsip kimiawi lempung?

9. Apakah bahan perkuliahan yang anda gunakan telah mengkaitkan antara konten kimia bahan galian dengan konteks penelitian laboratorium?

10. Menurut anda, perlukah perkuliahan kimia bahan galian dirancang menjadi suatu prospek penelitian laboratorium? apa alasan anda?

Pertanyaan nomor 1 dan 2 hanya $40 \%$ menjawab pernah mendengar dan membacanya. Nomor 3 dijawab benar hanya 10\%. Melihat pola jawaban yang diberikan 10 mahasiswa, dapat diketahui bahwa pengetahuan mahasiswa tentang 
batu gamping sebagai prospek PL kimia masih sangat minim (blank mind). Pertanyaan nomor 4 hanya dijawab benar (30\%), selebihnya pada penggunaan secara fisik saja. Nomor 5, 100\% menjawab secara singkat tanpa penjelasan konkrit. Pertanyaan nomor 6 sebanyak 20\% memberikan alasan dengan sikap yang diinginkan. Pertanyaan nomor 7 dijawab baik oleh $70 \%$ mahasiswa. Pertanyaan nomor 8 dijawab $100 \%$ mahasiswa pendapat yang sangat dangkal. Pertanyaan nomor 9 dijawab $100 \%$ mahasiswa, dengan tidak ada keterkaitan antara PL dengan mata kuliah. Pertanyaan nomor 10, $100 \%$ menunjukkan respon yang sangat baik. Berdasarkan wawancara tersebut dapat dikatakan $>80 \%$ mahasiswa sangat minim memahami lempung sebagai prospek penelitian kimia. Sehingga perlu dimunculkan perkuliahan PL konteks batu gamping berbasis PSDM untuk lebih menggali pola berpikir mahasiswa.

\section{PENUTUP}

Temuan dan analisis data penelitian memiliki karakteristik bahan ajar yang dikembangkan melalui MER yaitu: bahan ajar dikembangkan sesuai dengan aspek kompetensi dan sikap PSDMMBTI, konteks pembelajaran disesuaikan dengan isu sosial-ilmiah (PSDM) dan kurikulum 2013, konten perkuliahan disesuaikan dengan tingkat kognitif mahasiswa kriteria accesible, peracangan bahan perkuliahan menggunakan urutan pengajaran STL yang berisi pendahuluan, intisari, dan dengan tahap perkuliahan berbasis PSDM, konsep PL konteks kimia batu gamping yang berbasis PSDM. Pertama Perspektif mahasiswa terhadap isu PL konteks batu gamping berbasis PSDM digali melalui hasil wawancara, $>80 \%$ prakonsepsi salah terhadap penelitian.

Kedua penilaian bahan ajar keseluruhan meliputi, 1) Ketepatan materi (konten dan konteks), 2) Kesesuaian antara konten dan konteks, 3) Kesesuaian materi dengan kurikulum (tujuan pembelajaran), 4) Ketepatan gambar dan tugas percobaan, dan 5) Kesesuaian materi dengan kemampuan mahasiswa. Berdasarkan poin penilaian tersebut maka diperoleh CVR rata-rata untuk bahan ajar perkuliahan adalah $0,84, \mathrm{CV}_{\mathrm{Ih}}$ > $\mathrm{CV}_{\text {It }}(0,84>0,73)$ ini menandakan bahwa bahan modul perkuliahan yang dikembangkan layak digunakan untuk mahasiswa pendidikan kimia.

\section{DAFTAR PUSTAKA}

Donnel CM, Cristine O, Michael K S, 2007. "Developing Practical Chemistry Skill by Means of Students-Driven Problem Based Learning Mini-Projects Mini". Journal Chemistry Education Research and Practice. 8(2):130-139.

Duit R, Harald G, Kattmann U, Komorek M, Ilka P. 2012. "The Model of Educational Reconstruction-A Framework for Improving Teaching and Learning Science" Science Education Research and Practice in Europe.

Huitt GW. 1992. "Problem solving decision making, consideration of individual differences using the Meyers Briggs Type Indicator, [online] Avalaible: http://www.edssyanteractive.org/pgpers/prbs $\mathrm{m}$.

Ross MS. Morrison GR. 2003. Hand Book: Research Methods in Experimental. The University of Memphis \& Wayne State University. Aect.org/edtech/ed 1/38 pdf. 